\title{
プリント基板穴あけ用 $\mathrm{CO}_{2}$ レーザ加工機
}

\author{
今井祥人*, 祝 靖彦**
}

\section{$\mathrm{CO}_{2}$ Laser Drilling Machine for PCBs}

\author{
Yoshihito IMAI and Yasuhiko IWAI
}

\section{1.はじめに}

近年, 携帯電話や情報端末機器の小型化, 高機 能化に伴い, そこに使用されるプリント基板の高 密度化, 微細化が急速に進んでいる. 特にプリン ト基板の製造方法では, 従来のドリルによるスル 一ホール加工から，レーザによるビアホール加工 が多く利用されるようになり, また穴径も $300 \mu \mathrm{m}$ 程度から $100 \mu \mathrm{m}$ 以下と, 微細化の要求が高まって いる.

このような要求に対して, $\mathrm{CO}_{2}$ レーザを用いた プリント基板穴あけ用のレーザ加工機が製品化さ れ, 穴径 $100 \mu \mathrm{m}$ 前後の微小穴を高速・高精度に加 エすることが可能となっている ${ }^{1)}$. また, 穴径 $50 \mu \mathrm{m}$ 以下では, UV-YAG レーザを用いることで 高精度加工 ${ }^{2)}$ が可能であるが, 本格的に量産ライ ンに適用されるのは $2 \sim 3$ 年後と推定される.

ここでは，プリント基板の穴あけ加工において 強く要求されている高生産性, および高信頼性を 実現するための技術について $\mathrm{CO}_{2}$ レーザマルチビ 一ム加工機を例に紹介する. なお，加工技術に関 しては他の文献3，4）を参照していただきたい.

\section{2. レーザ加工機の構成と加工例}

レーザによるプリント基板の穴あけ加工機の典 型的な構成例 (シングルビーム加工機) をFig. 1 に示す.レーザ発振器から発振されたレーザ光は, コリメーションレンズ, マスク等からなる光学系

* 三菱電機(株) 先端技術総合研究所 (尼崎市塚口本町 8-1-1)

** 三菱電機(株) 名古屋製作所 (名古屋市東区矢田南 5-1-14)
を通過した後, ガルバノスキャナへと導かれる. ガルバノスキャナは, NC 制御装置からの指令值 に基づきミラーを所定の角度に制御し，レーザ光 を $\mathrm{f} \theta$ レンズへと導く.レーザ光は $\mathrm{f} \theta$ レンズで 集光され，プリント基板に照射されることで穴あ け加工が行われる. ガルバノスキャナは, 高速に ビームを位置決めすることが可能であるが，加工 できる範囲（スキャンエリア）は $\square 30 \sim \square 70 \mathrm{~mm}$ と制限がある. そのため, プリント基板上（たと えばサイズ $500 \times 600 \mathrm{~mm}$ ) の加工エリアは複数のス キャンエリアに分割され，一つのスキャンエリア 内の加工が終了すると, プリント基板を XY テー ブルで移動させ, 次のスキャンエリア内の加工を 行う.この一連の動作を繰り返すことによりプリ ント基板の全面加工が可能となる.

Fig. 2 (a) は $\mathrm{CO}_{2}$ レーザによりガラスエポキシ系 基板に直径 $200 \mu \mathrm{m}$ のビアホール加工を行った例 である. ガラスを含む材料では, 高ピーク・短パ ルス化されたレーザを利用することで, 大幅な加 工品質の改善が可能となる. また, Fig. 2 (b) は工 ポキシ系基板に直径 $150 \mu \mathrm{m}$ のビアホール加工を 行い, 銅めっき処理を行った例であり, 側面にテ 一パーのない穴加工が実現できている. それぞれ の加工は，底面の銅箔部分でレーザが反射さるた め銅箔のところで止まっている.

Fig. 2 (c)， (d) は，ポリイミド系基板にそれぞ

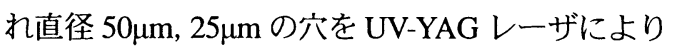
加工した例である. 


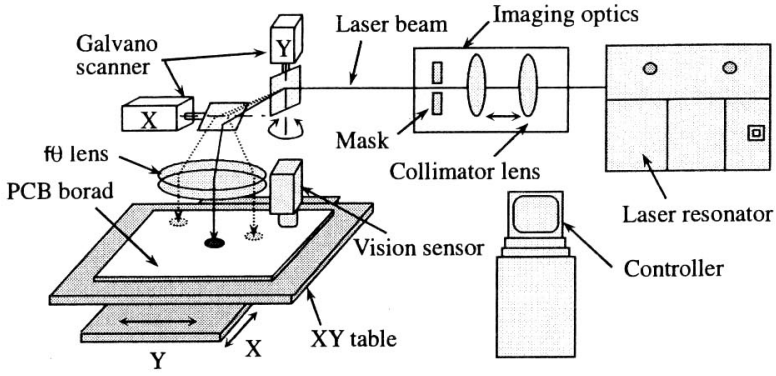

Fig.1 Typical Configuration of Single Beam Machine.

\section{3. 加工機の高生産性}

プリント基板の穴あけ加工において高生産性を 実現するためには, 特に次の 3 つの技術が重要と なっている.

（1）プリント基板加工用 CAD 変換

(2) マルチビーム加工方式

(3) 高速ガルバノスキャナシステム

以下，それぞれの技術について紹介する.

\section{1 プリント基板加工用 $\mathrm{CAD}$ 変換}

プリント基板加工用 $\mathrm{CAD}$ 変換では, 基板全体 の穴位置情報を含むガーバーデータからガルバノ スキャナで加工するスキャンエリア分割とそのエ リア内において加工する穴の順番を決定する. そ の際, スキャンエリア分割数が最小となるように, また加工時のガルバノスキャナ移動距離が最小と なるように決定し，XY テーブルの駆動用 NC コ 一ド，ガルバノスキャナの駆動用指令データを自 動生成する. Fig. 3 は, Fig. 1 に示すシングルビ 一ム加工において，ガーバーデー夕より単純に工 リア分割と穴加工順番を決定したもの (左側) と, 最適化アルゴリズムにより決定したもの (右側)を 示す.エリア分割数, ガルバノスキャナ移動距離 は明らかに最小化されており, 加工時間の短縮が 可能となる. この最適化では, ニューラルネット ワークや遺伝的アルゴリズムなどが利用される. なお，次に紹介するマルチビーム加工方式では，

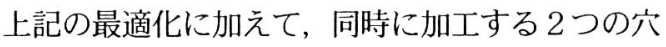
の選択についても最適化を行い, 加工時間の短縮 を実現している.

\section{2 マルチビーム加工方式}

加工時間を短縮する手段として, 従来のシング ルビームに替えて, 以下のように同時, あるいは

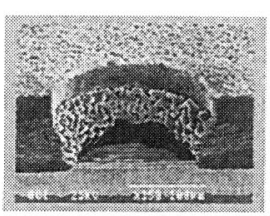

(a) $\phi 200 \mu \mathrm{m}$, epoxy-glass.

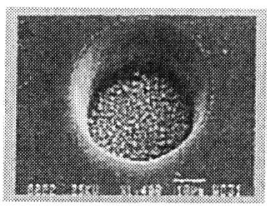

(c) $\phi 50 \mu \mathrm{m}$, polyimide.

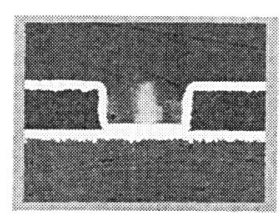

(b) $\phi 150 \mu \mathrm{m}$, epoxy.

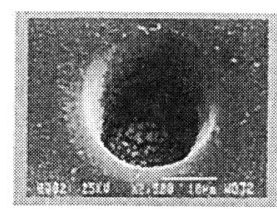

(d) $\phi 25 \mu \mathrm{m}$, polyimide. (a),(b): by $\mathrm{CO} 2$ laser, (c),(d): by UV-YAG laser.

Fig.2 Examples of Via-holes.
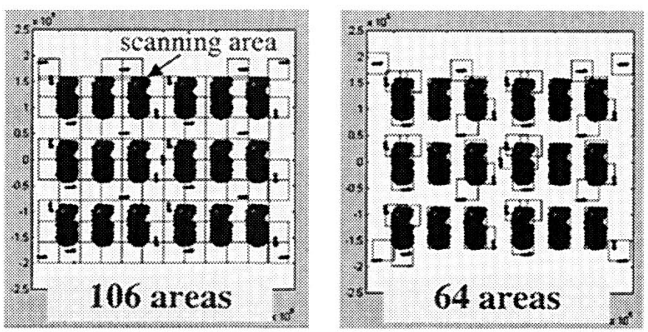

(a) number of scanning area.
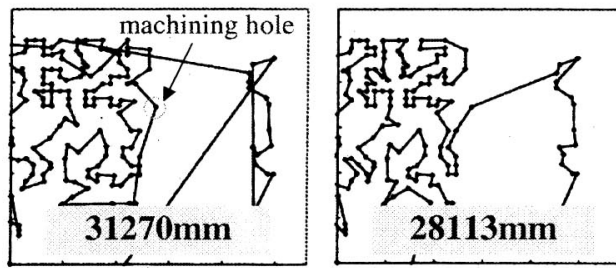

(b) traveling distance.

Fig.3 Minimization of machining time by CAD.

並列して加工を行うことが考えられる.

(1)レーザ発振器から出たビームを 2 つのビー ムに分光し，1つのスキャニングシステムへ供給.

(2)レーザ発振器から出たビームを 2 つのビー ムに分光し，異なる2つのスキャニングシステム へ供給.

(3)レーザ発振器から出たビームを時分割し, 異 なる 2 つのスャニングシステムへ供給.

一般に，(1) はマルチビーム加工方式，(2)，(3) はマルチヘッド加工方式と呼ばれる.

マルチビーム加工方式は，上述のように 1つの スキャンエリア内の異なる 2 箇所を同時に加工す 


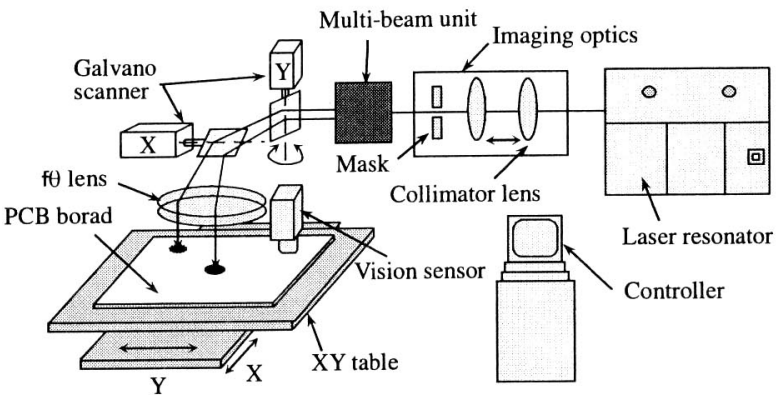

Fig.4 Configuration of Multi Beam Machine.

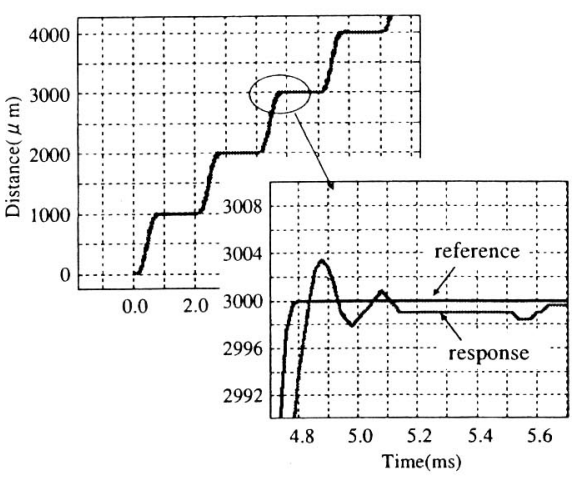

Fig.5 Step response of galvano scanner.

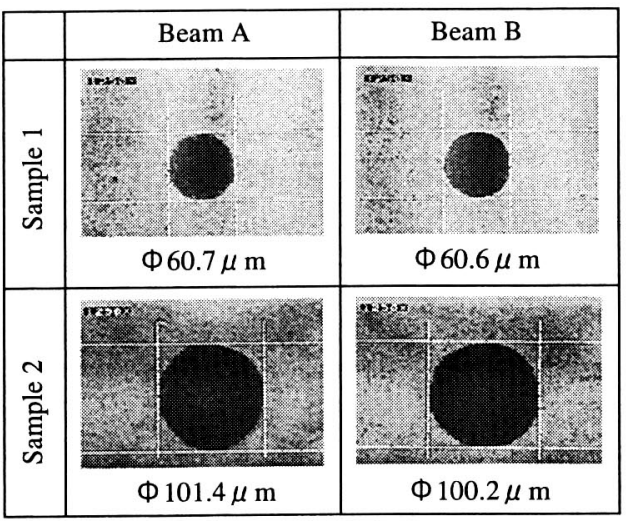

Fig.6 Via-holes drilled by Multi Beam.

さらに高分解能低イナーシャ位置センサの採用な ど，あらゆる部分の最適化を実施している. Fig. 5 はガルバノスキャナを 1200 ポイント/秒 $(1 \mathrm{~mm}$ ピッチ) で駆動した場合の時間応答波形である.

\section{4. 加工機の高信頼性}

マルチビーム加工機は、以上のような技術によ り高生産性を実現しているが, 同時に, 加工穴の 位置精度や品質など, 高信頼性を保証することが 不可欠である.

レーザ発振器においては, レーザ出力安定化技 術やレーザパルスのエネルギモニタリング機能な どが組み込まれており, 加工穴毎の品質のばらつ きを抑えることができる. また，マルチビーム加 工方式では， 2 つのレーザ光の光路構成を統一す るとともに，それらのレーザ光のエネルギーバラ ンスが調整できるようにエネルギ一調整機能を開 発し, 加工穴の品質を保証している. Fig. 6 はマ 
ルチビームで加工した場合，(Beam A と Beam B) の一例であり，ほぼ同形の穴が加工されている. 高速ガルバノスキャナシステムにおいては, 温 度変動に強い位置センサを採用し，また光路系や f $\theta$ レンズが持つ非線形特性を補償するガルバノ 補正機能を実現することで，加工穴の位置精度を 保証している. Fig. 7 は, マルチビームで加工し た加工穴の位置精度の評価結果を示す．スキャン エリア内を格子状に等間隔に並ぶ 25 点の加工穴 位置において, 目標位置からのX方向, Y方向の 誤差をあらわしている. 上段はガルバノ補正直後, 下段が 6 時間後のデータである. Beam A と Beam $\mathrm{B}$ は，お互いの位置関係がずれることなく，位置 決め誤差 $\pm 10 \mu \mathrm{m}$ 以下を実現している.

以上，これらの最新技術を搭載した基板穴あけ 用 $\mathrm{CO}_{2}$ レーザマルチビーム加工機[ML605GTXIII (-M)-5100U2]を Fig. 8 に示す. また, Table 1 に加 工機の仕様をまとめる.

\section{5. おわりに}

$\mathrm{CO}_{2}$ レーザマルチビーム加工機を例として, プリ ント基板の穴あけ加工で要求される高生産性, 高 信頼性を実現する技術を中心に紹介した.今後も, 高生産性, および微細穴化への要求はさらに高ま る. $\mathrm{CO}_{2}$ レーザに替えて，UV-YAG レーザへの期 待は大きく, 量産ラインで使用されるためには, レーザ発振器の大出力化, 高信頼化, またガルバ ノスキャナを中心としたビーム位置決め速度, 精 度の大幅な向上が不可欠であろう。

\section{参考文献}

1) 水野, 福島, 金岡, 西前, 今井, 竹野: 新用途老開拓する 短パルス $\mathrm{CO}_{2}$ レーザ加工機。三菱電機技報,

Vol.71, №.4,(1997), pp.41-46.

2）磯: UVレーザドリリングマシン, 電子材料,

Vol.10,(2002),pp.85-88.

3）廣崎, 福島, 金岡 : $\mathrm{CO}_{2}$ レーサによよるプリント基板の穴あ 协加, レーサ熱加研究会誌 V615,No.2,(1998),pp.97-103.

4）門屋 : プリント基板へのレーザ加士応用の現状，レーサ熱 加士研究会誌、Vol5, No.2,(1998), pp.124-125.

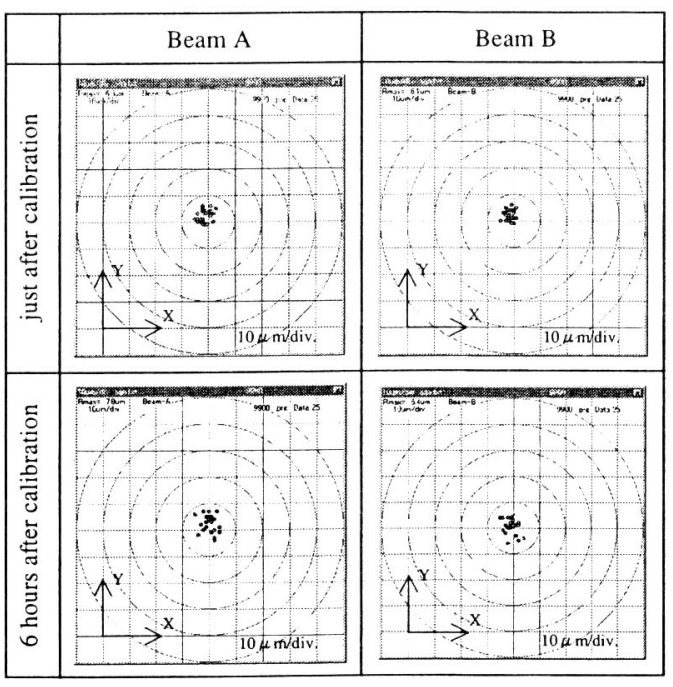

Fig.7 Positioning error after calibration for Multi Beam.

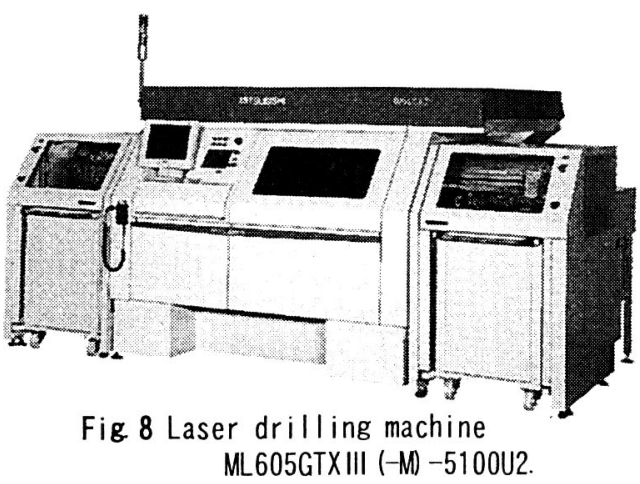

Table 1 Specification of ML605GTXIII $(-M)-510002$. $\mathrm{XY}$ table

\begin{tabular}{l|c} 
Stroke[mm] & $620 \times 510$ \\
Max feed rate[mm/min] & 50 \\
Zstroke [mm] & 80 \\
Scanning Freq.[Hz] & 1200 \\
\hline Laser type & $\mathrm{CO} 2$ laser \\
Output power $(\mathrm{W})$ & 100 \\
Pulse frequency $(\mathrm{Hz})$ & $10-5000$ \\
Pulse duration $(\mu \mathrm{s})$ & $1-100$ \\
\hline
\end{tabular}

(2003 年 10 月 15 日受付) 